\title{
Barriers Facing Postpartum Family Planning among Women Attending Family Medicine Units in 6th of October City
}

Kholoud Mansour ${ }^{*}$, Dalia Gaber ${ }^{2}$, Ghada Wassef ${ }^{2}$, Maha El Gaafary ${ }^{2}$

${ }^{1} \mathrm{MOH}$, Egypt, ${ }^{2}$ Department of Community, Environmental and Occupational Medicine, Faculty of Medicine, Ain Shams University

\section{Abstract:}

Background: Globally, family planning (FP) is a key life-saving intervention for mothers and their children; Postpartum Family Planning (PPFP) aims to prevent the high risk of unintended and closely spaced pregnancies during the first year following childbirth. Given the high unmet need for family planning during the postpartum period, this has raised the need to identification of the main barriers to provide methods of solutions. One of which is the need to integrate FP information and service provision during post natal care, child health care visits, and all levels of the health system. Objectives: This study aims to measure the rate of PPFP among women attending family medicine units in $6^{\text {th }}$ October city and to identify the effect of PPFP on pregnancy spacing as well as the main barriers facing its continuation. Methods: This study is a cross-sectional analytic study; it was conducted between July and October 2017 on married women in reproductive age attending three family medicine centers. Data were collected through a structured interviewed questionnaire based on concept definition of Postpartum Family Planning (PPFP) ; the prevention of unintended pregnancy and closely spaced pregnancies through the first 12 months following childbirth Results: About Sixty percent (59.4\%) of women were between 25-35 years with a mean age of $30 \pm 6.4$ years. The rate of PPFP is $51.8 \%$, more than half of studied women reported that" lack of knowledge on FP" is the main barrier to contraception use, followed by "desire to get more children" $42.2 \%$. Conclusion: Family physicians should be committed to clarify the concept of PPFP aiming at increasing women's awareness and compliance to the best contraceptive methods.

Key words: Barriers, Continuation, Family planning, Postpartum, Spacing

Introduction: The first year after childbirth is a period when a subsequent pregnancy holds the greatest risk for the mother and the baby. Needless to say that family planning is invaluable to postpartum women. and these women have multiple contacts with the health facility either for postnatal or child immunization visits. ${ }^{(1)}$

Postpartum family planning (PPFP) is defined as; the prevention of unintended pregnancy and closely spaced pregnancies through the first year after childbirth. ${ }^{(2)}$

The PPFP has been recognized as an imperative component of maternal health care, through birth spacing and prevention of highrisk and undesired pregnancies, it helps women who have recently delivered to avoid exposure to the risks of maternal death. ${ }^{(3)}$

Closely spaced pregnancies within the first year postpartum result in increased risks for adverse outcomes, such as preterm, low birth weight and small for gestational age, ${ }^{(4)}$ FP can prevent more than $30 \%$ of maternal deaths and $10 \%$ of child mortality if couples space their pregnancies more than 2 years apart $^{(5)}$.and under-five mortality would decrease by $13 \%$, if couples waited 36 months, the decrease would be $25 \%{ }^{(6)}$

Corresponding author: Kholoud Mansour Abd-El Aziz (kholoud_mansour@yahoo.com) 
Family planning services for postpartum women require unique physiological considerations; Postpartum women experience amenorrhea, and their fertility can return before menses resumes, even when breastfeeding $^{(7)}$. PPFP programs also must understand the clinical safety standards applied to different contraceptive methods across the 12-month period following birth, taking the mother's breastfeeding status into special consideration.

Since the inception of the National Population Program in the mid-60s, Egypt has made significant strides in lowering fertility levels, from a total fertility rate (TFR) of 5.3 in 1980 to 3.0 in 2008 according to Ministry of Health and Population (8). However, the TFR has since risen to 3.5 in 2014.

According to last demographic health survey in Egypt, around 3 in 10 users in Egypt stop using a method within 12 months of starting use (8) and according to WHO recommendation; an important consideration when planning a PPFP intervention is women safety regarding the use of contraception among women during the first year postpartum and beyond. ${ }^{(2)}$

A woman who is exclusively breastfeeding can use the lactational amenorrhea method (LAM) for up to 6 months following a birth, ${ }^{(9)}$ a copper-bearing intrauterine contraceptive device (IUD) or all progestogen-only methods. ${ }^{(10)}$ Nonbreastfeeding women, in addition to IUD, progestogen-only methods, combined oral contraceptives can be used. (10) All women postpartum can use condoms, emergency contraception, and the diaphragm or cervical cap. $^{(11)}$

The most effective reversible methods of contraception are IUDs and contraceptive implants. ${ }^{(12)}$ The main reasons behind not using a contraceptive method during the first year postpartum, paying attention to reasons that may reflect postpartum insusceptibility: postpartum amenorrhea, breastfeeding, no sex, or infrequent sex, ${ }^{(13)}$ side effects and health concerns were the reasons that users most often cite for stopping using, method failure, female want to become pregnant. ${ }^{(8)}$

Other barriers include problems at the health facility level, barriers to demand for PPFP, and weaknesses in underlying health system functions needed to support PPFP services. ${ }^{(14)}$

Because of lack of information about PPFP, and its barriers in our society the study was conducted to submit more information for promoting the impact of Post-Partum Family Planning (PPFP). This study aimed to measure the rate of PPFP among women 
attending family medicine units in $6^{\text {th }}$ October city. Also, this study aimed to identify the effect of PPFP on pregnancy spacing as well as the main barriers facing continuation of PPFP.

Methods: This study is a cross-sectional analytic study; it was conducted between July and October 2017. It was conducted on 384 Married women in the reproductive age attended the three family medicine centers $\left(6^{\text {th }}\right.$ district, Al_shabab family medicine unit, Al mostakbal family medicine unit) in $6^{\text {th }}$ October city. The following inclusion criteria were considered; healthy women, free from any systemic disorders, married females in reproductive age (18-49 years) and married female with -at least- one living child at least 1-year-old. However the exclusion criteria were: Primary or secondary infertility and repeated abortion (the consecutive loss of three or more clinically recognized pregnancies prior to the $20^{\text {th }}$ week of gestation (excluding ectopic or molar pregnancies). ${ }^{(15)}$

Sampling and sample size: Participants were recruited from three the family medicine units, in a systematically random way along period of 4 months (from July to October 2017) two days per week in average of twelve participants every visit. A sampling interval was calculated by dividing the targeted population by the sample size desired on daily base considering an average daily sample size of about 70 women. the sample was calculated using Epi-info 7.1 program putting in consideration that the prevalence of contraception usage among Egyptian females is $57.5 \%,{ }^{(16)}$ at a confidence level of $95 \%$.

Study tools: Data were collected through an interview questionnaire; validity was gotten from "Community, Environment and occupational medicine" department of Ain shams university.

The questionnaire included the following items:-

1. Personal data (e.g. couple's age, couple's educational level, occupation, etc.) and reproductive history for participants (pregnancy number, abortion number, number of boys and girls)

2. The participants' concept on family planning regarding; their knowledge about family planning concept, different available methods and her personal experience as well.

3. The current and previous use of family planning method, side effects and its complications.

4. Causes of unmet need for participants if present.

5. The main barriers for participants to use family planning methods.

Data management: Data were collected and statistically analyzed using SPSS package for 
windows (statistical package for social science) program version 20, SPSS Inc., and Chicago, Illinois, USA

Ethical consideration: Approval from faculty of medicine Ain Shams University, ethical committee was obtained. Administrative approval from the director of the $6^{\text {th }}$ district family medicine, Al_shabab and Al_mostakbal centers was taken. Questionnaire used was anonymous; confidentially of data was assured.

Results: Out of 384 women attending three family health centers in $6^{\text {th }}$ October city distributed as follow: (60.4\%) of the participants were interviewed in (AlMostakbal) family health unit, (26.8\%) of them from ( $6^{\text {th }}$ district) family health unit and from (Al Shabab) family health unit (12.8\%). more than half of studied women $(59.4 \%)$ were between 25-35 years with a mean age of $30 \pm 6.4$, the majority of studied women $(82.8 \%)$ were non pregnant, less than half of studied women were with intermediate education $(44 \%)$ and more than two third were house wives (78.9\%). On Asking on the husbands' education and profession, it was found that $(46.9 \%)$ of husbands have completed high school and the majority of them were skilled worker $(81.5 \%)$. Half of them $(50.5 \%)$ reported having an average income between (1000-1999L.E), Table (1).
The rate of PPFP in previous use was $(62.0 \%, 64.7 \%, 61.2 \& 65 \%)$ in $1^{\text {st }}, 2^{\text {nd }}, 3^{\text {rd }}$ $\& 4^{\text {th }}$ previous method used respectively and $(51.8 \%)$ in current use.

As for the reasons for using FP methods, the study revealed more than half $(59.1 \%)$ of studied women mentioned that " birth spacing " was the main reason for using FP methods in $59.1 \%$ of the studied participants, followed by " temporarily delaying of pregnancy" in (47.7\%) of them, "stopping conception after getting desire number of children" (25.3\%), "prevention of pregnancy forever "(4.4\%) and nearly $(1.3 \%)$ used a method due to their medical conditions.

On assessing the 5 barriers for PPFP use among the participants, more than half of studied women $(59.6 \%)$ reported that" lack of knowledge about FP" was the main barrier to method use, followed by "desire to get more children" (42.2\%),"afraid of side effect" (34.6\%),"husband and family desire" (33.6\%) and about (12.5\%) mentioned "desire to use natural methods " as seen in Figure (1).

Table (2) shows that the majority of studied women (94.7\%) "who were not pregnant " were using contraceptive methods at time of study with a mean duration $(27.6 \pm 8.7)$, the mean time for initiation of postpartum FP method used was (3.2 \pm 4.3$)$ months, regarding the type of contraceptive 
method used, (40.5\%) of participants used IUD, and about one third (33.2\%) used OCP, $(16.3 \%)$ used injection, (6\%) used capsule and (4\%) used condom.

In addition, more than half $(52.1 \%)$ of participants indicated that the follow up for the used FP method was done in its proper timing through their health care providers.

The current study found that the most commonly used method in previously uses$1^{\text {st }}-4^{\text {th }}$ usage of contraceptive methods- by participants was OCP by ranging from $(35 \%$ $47.1 \%)$, followed by IUD (27.9\%-39.9\%), on the other hand, IUDs were the most commonly used as a current FP method as mentioned by $(40.5 \%)$ of participants followed by OCP (33.2\%) as seen in Figure (2).

Regarding side effects occurrence with current use, Table (3) shows that there is highly statistically significant relationship between occurrence of menstrual disorder and vaginal infection with the current use of PPFP method $(\mathrm{P}<0.01)$, where menstrual disorder was highest among women who used injection $(28.0 \%)$,while vaginal infection was highest among women who used IUD (16.4\%),however, there is statistically insignificant relationship between occurrence of bleeding ,weight gain and GIT disturbance with current use of PPFP method ( $\mathrm{P}>0.05)$.
Discussion: The current study was conducted in three family medicine centers in $6^{\text {th }}$ October city to explore various aspects of PPFP. More than half of studied women were between 25 35 years with a mean age of $30 \pm 6.4$, this agrees with Handady et al, 2015 ${ }^{(17)}$ study done in primary health center in Khartoum in Sudan among 400 women who found that the participants' women were of the same sociodemographic characters and these reflect that this reproductive age had highest fertility and that poor low socioeconomic level seek $\mathrm{PHC}$ and central hospital as it provides almost free and accessible family planning services.

In present study more than half $(59.1 \%)$ of the participants mentioned that " birth spacing " was the main reason for using FP methods, followed by " temporarily delaying of pregnancy" (47.7\%), "stopping conception after getting desire number of children" (25.3\%), "prevention of pregnancy forever "(4.4\%) and nearly (1.3\%) used a method due to their medical conditions ,these finding agrees with Choudhary et al,2015 ${ }^{(18)}$ who reported that the main reason for FP using was "Birth spacing" (92.5\%), then "limiting family size "(40.0\%) in his study carried out on 400 antenatal women attending the antenatal clinic of a tertiary teaching hospital in North India. however, this findings differ with Prachi et al,2008 ${ }^{(19)}$ as the mean reason in his study 
was found to be "preventing unwanted births" $(83.5 \%)$ and only $29.8 \%$ said it was for "birth spacing".

In Egypt family planning is used mainly to ensure good spacing and to temporarily delay not for limiting the number of children as they believe that it is unaccepted from religious point of view. The current study shows that "Lack of knowledge about FP "was the main barrier of using FP method as mentioned by study participant as general, followed by "Desire to get more children", "Afraid of side effect occurrence " and " Husband and family desire".

These findings were consistent with the study carried out by Choudhary, Pal, and Goel, in $2015^{(18)}$ in which the main barrier was Lack of knowledge. on other hand disagree with Prachi et al,2008 ${ }^{(19)}$ study where the main barrier was desire to have a child, Lack of knowledge, religious beliefs.

Lack of knowledge come first in current study as they use family planning methods in wrong way, e.g: natural methods like Lactating amenorrhea without fulfilling its characteristics or safe period with irregular period.

As regards postpartum family planning current practice, the study shows that the majority of studied women (94.7\%) "who were not pregnant " used contraceptive methods at time of study, for a mean duration $(27.6 \pm 8.7)$, the mean time for initiation of postpartum FP method used was (3.2 \pm 4.3$)$ months, regarding the type of contraceptive method used, (40.5\%) of participating non pregnant women used IUD, and about one third used OCP, followed by injection and low percent $(6 \%)$ used capsule and (4\%) used condom. Similar findings were reported in EDHS $2014^{(8)}$ where, the most widely used method is the IUD followed by the pill and injectable. However, it disagrees with previous use by participants in the present study.

Women in Egypt prefer using the IUD as it is the most effective reversible method and doesn't require self-timing to remember it as pills, easily accessible in PHC units with trained doctors and with low cost followed by pills (that come first in previous usage) as it easy with no need for doctor intervention and can used for short term but need good timing.

A strong statistically significant relationship was reported in the current study between occurrence of menstrual disorder and vaginal infection with the current use of PPFP method $(\mathrm{P}<0.01)$, where menstrual disorder was highest among women who used injection $(28.0 \%)$ this agree with study done in Nigeria by ${ }^{(20)}$ who found that menstrual disorders were the most common complications from injections . 
Vaginal infection was highest among women who used IUD (16.4\%), it agrees with Madden et al $2012^{(21)}$ where the incidence of BV was $37.0 \%$ among IUD users.

Also a statistically insignificant relationship was found between occurrence of bleeding, weight gain and GIT disturbance and current use of PPFP method $(\mathrm{P}>0.05)$; however, bleeding was highest among IUD users (9.8\%) which agrees with study done by Lara-Torre et al. 2011 (22) in Carilion Clinic in Virenia as bleeding disorder was the main side effect of IUD followed by pain and vaginal infection.

\section{References:}

1. Speizer IS, Fotso JC, Okigbo C, Faye CM, Seck C. Influence of integrated services on postpartum family planning use: a crosssectional survey from urban Senegal. BMC Public Health. 2013;13(1):752.

2. WHO. Programming strategies for postpartum family planning. 2013.

3. Akinlo A, Bisiriyu A, Esimai O. Influence of use of maternal health care on postpartum contraception in Nigeria. 2013.

4. DaVanzo J, Hale L, Razzaque A, Rahman M. Effects of interpregnancy interval and outcome of the preceding pregnancy on pregnancy outcomes in Matlab, Bangladesh. BJOG: An International Journal of Obstetrics \& Gynaecology. 2007;114(9):1079-87.

5. Cleland J, Bernstein S, Ezeh A, Faundes A, Glasier A, Innis J. Family planning: the unfinished agenda. The Lancet. 2006;368(9549):1810-27.
6. Rutstein SO. Further evidence of the effects of preceding birth intervals on neonatal infant and under-five-years mortality and nutritional status in developing countries: Evidence from the Demographic and Health Surveys. 2008.

7. Jackson E, Glasier A. Return of ovulation and menses in postpartum nonlactating women: a systematic review. Obstetrics \& Gynecology. 2011;117(3):657-62.

8. El-Zanaty F, Way AA. Egypt Demographic and Health Survey 2014. 2015.

9. Fabic MS, Choi Y. Assessing the quality of data regarding use of the lactational amenorrhea method. Studies in family planning. 2013;44(2):205-21.

10. Kapp N, Curtis K, Nanda K. Progestogen-only contraceptive use among breastfeeding women: a systematic review. Contraception. 2010;82(1):17-37.

11. Cleland J, Conde-Agudelo A, Peterson $\mathrm{H}$, Ross J, Tsui A. Contraception and health. The Lancet. 2012;380(9837):149-56.

12. Blazer C, Prata N. Postpartum family planning: current evidence on successful interventions. Open Access Journal of Contraception. 2016;7:53-67.

13. Rossier C, Bradley SE, Ross J, Winfrey W. Reassessing unmet need for family planning in the postpartum period. Studies in family planning. 2015;46(4):355-67.

14. Chitashvili T, Holschneider S, Clark P. Improving quality of postpartum family planning in low-resource settings. A 
framework for policy makers managers and medical care providers. 2016.

15. Paukku M, Tulppala M, Puolakkainen M, Anttila T, Paavonen J. Lack of association between serum antibodies to Chlamydia trachomatis and a history of recurrent pregnancy loss. Fertility and sterility. 1999;72(3):427-30.

16. Awadalla HI. Contraception use among Egyptian women: results from Egypt demographic and health survey in 2005. Journal of Reproduction \& Infertility. 2012;13(3):167.

17. Handady SO, Naseralla K, Sakin HH, Alawad AAM. Knowledge, attitude and practice of family planning among married women attending primary health center in Sudan. Int J Public Health Res. 2015;3(5):243-7.

18. Choudhary D, Pal R, Goel N. Awareness and practice patterns of family planning methods among antenatal women in Indian community: Are we hitting the bull's eye. Biochem J. 2015;38(4):356-8.
19. Prachi R, Das GS, Ankur B, Shipra J, Binita K. A study of knowledge, attitude and practice of family planning among the women of reproductive age group in Sikkim. Religion. 2008;35(44years):34.

20. VK O, Okongwu C. A-Five Year Review of the Complications of Progestogen only Injectable Contraceptive at the University of Port-Harcourt Teaching Hospital. Nigerian Journal of Medicine. 2010;19(1).

21. Madden T, Grentzer JM, Secura GM, Allsworth JE, Peipert JF. Risk of bacterial vaginosis in users of the intrauterine device: a longitudinal study. Sexually transmitted diseases. 2012;39(3):217.

22. Lara-Torre E, Spotswood L, Correia N, Weiss PM. Intrauterine contraception in adolescents and young women: a descriptive study of use, side effects, and compliance. Journal of pediatric and adolescent gynecology. 2011;24(1):39-41. 
Table (1): Socio-demographic characteristics of the studied women and their husbands

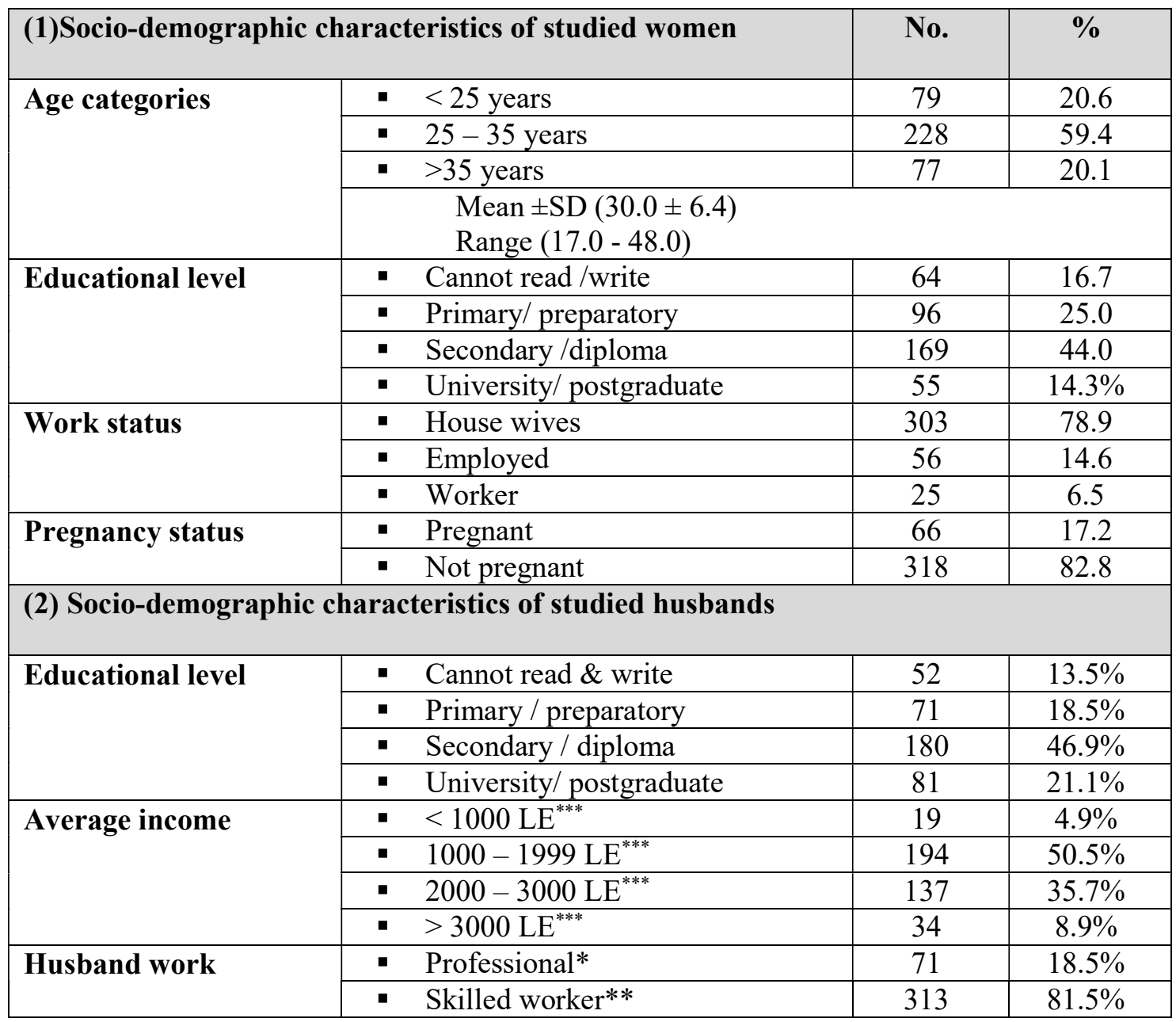

*Professional include: doctor, teacher, lawyer and accountant

** Skilled workers include: driver, worker, guard, carpenter, seller man, butcher and barber

${ }^{* * *}$ LE: Egyptian pound

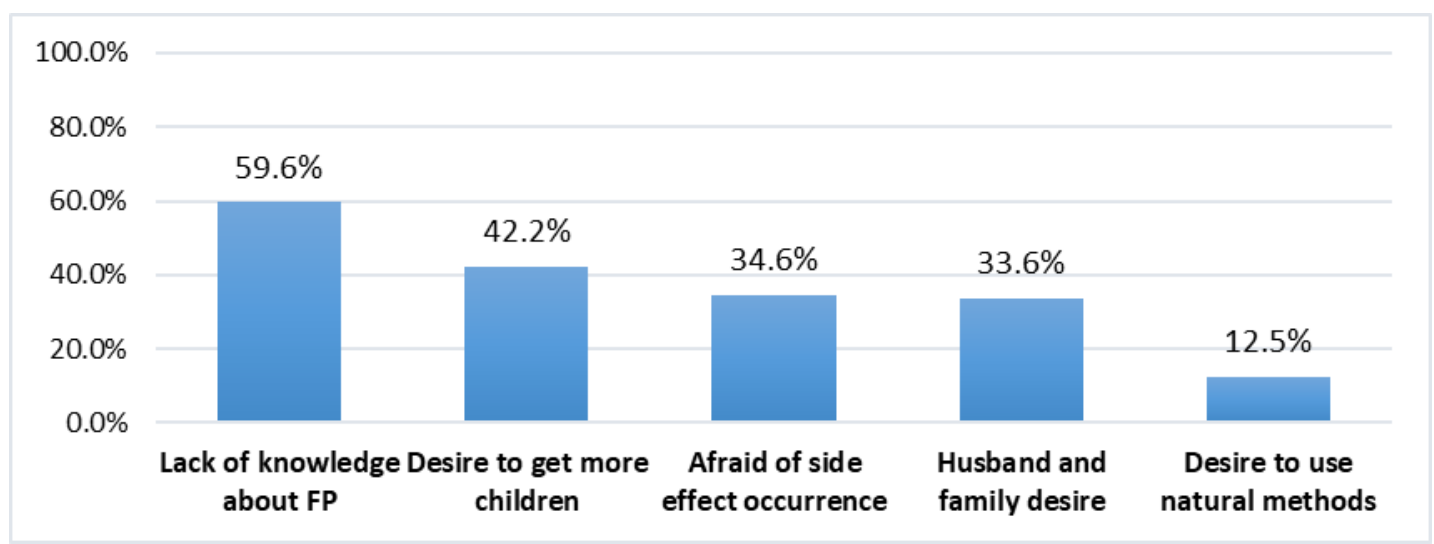

Figure (1): Top 5 barriers for PPFP use among women in general as mentioned by study participants $(\mathbf{n}=384)$

**More than one answer was allowed 
Table (2): Current use of FP methods among non-pregnant women and types of contraceptive methods used $(n=318)$ :

\begin{tabular}{|c|c|c|c|}
\hline \multicolumn{2}{|l|}{ Current use of $\mathrm{FP}^{*}$ methods } & \multirow{2}{*}{$\begin{array}{c}\mathbf{N} \\
301 \\
\end{array}$} & \multirow{2}{*}{$\begin{array}{c}\% \\
94.7 \% \\
\end{array}$} \\
\hline Current use of FP method & - Yes & & \\
\hline & - $\quad$ No & 17 & $5.3 \%$ \\
\hline $\begin{array}{l}\text { Duration of FP method use } \\
\text { (months) }\end{array}$ & \multicolumn{3}{|c|}{$\begin{array}{c}\text { Mean } \pm \text { SD }(27.6 \pm 18.7) \\
\text { Range }(2.0-120.0)\end{array}$} \\
\hline $\begin{array}{l}\text { Initiation of usage of FP } \\
\text { method (months) }\end{array}$ & \multicolumn{3}{|c|}{$\begin{array}{c}\text { Mean } \pm \text { SD }(3.2 \pm 4.3) \\
\text { Range }(1.0-39.0)\end{array}$} \\
\hline \multirow{7}{*}{$\begin{array}{c}\text { Type of contraception method } \\
\text { used }(n=301)\end{array}$} & - IUD ${ }^{\wedge}$ & 122 & $40.5 \%$ \\
\hline & - $\mathrm{OCP}^{\$}$ & 100 & $33.2 \%$ \\
\hline & - Injection & 49 & $16.3 \%$ \\
\hline & - Sub dermal capsule & 18 & $6.0 \%$ \\
\hline & - Condom & 12 & $4.0 \%$ \\
\hline & $\begin{array}{l}\text { - Exclusive breast } \\
\text { feeding }\end{array}$ & 0 & $0.0 \%$ \\
\hline & - $\quad$ Surgical & 0 & $0.0 \%$ \\
\hline \multirow{3}{*}{$\begin{array}{c}\text { Follow up of family planning } \\
\text { method }\end{array}$} & - $\quad$ Yes , in proper timing & 157 & $52.1 \%$ \\
\hline & - Occasionally & 92 & $30.5 \%$ \\
\hline & - No follow up & 52 & $17.2 \%$ \\
\hline
\end{tabular}

* FP: Family planning

${ }^{\wedge} I U D:$ Intrauterine Device

${ }^{\$} \mathrm{OCP}$ : Oral Contraceptive Pills

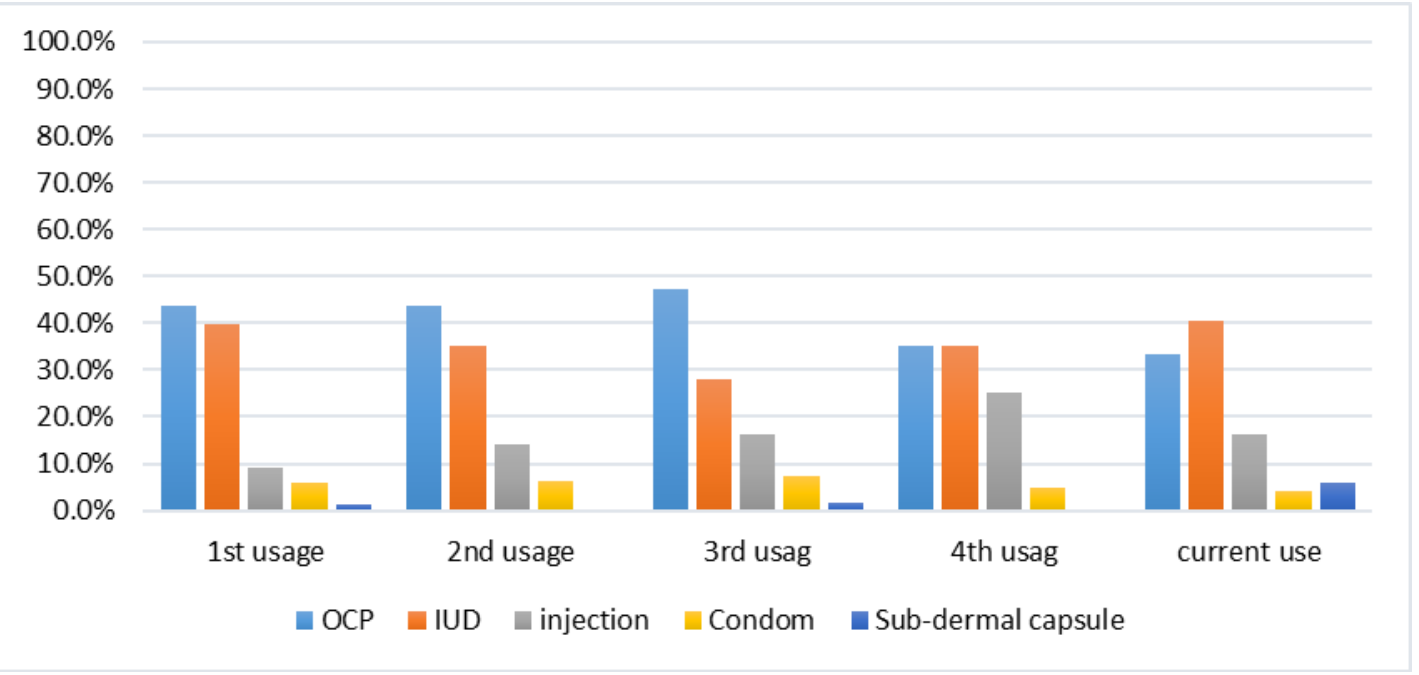

Figure (2): Comparison between current PPFP methods and Previous PPFP used by studied women 
Table (3) Relationship between current method used and different side effects occurred among studied women $(\mathbf{n}=\mathbf{3 0 1})$

\begin{tabular}{|c|c|c|c|c|c|}
\hline \multirow[t]{3}{*}{ Current method used } & \multicolumn{4}{|c|}{ Menstrual disorder (32) } & \multirow[t]{3}{*}{ Signficance } \\
\hline & \multicolumn{2}{|c|}{\begin{tabular}{l|l} 
Yes & \\
\end{tabular}} & \multicolumn{2}{|c|}{ No } & \\
\hline & $\mathbf{N}$ & $\%$ & $\mathbf{N}$ & $\%$ & \\
\hline - $\mathrm{OCP}^{\$}$ & 11 & $11.1 \%$ & 88 & $88.9 \%$ & \multirow{6}{*}{$\begin{array}{l}\mathrm{X}^{2}=22.007 \\
\mathrm{P}=.000 * *\end{array}$} \\
\hline - IUD $^{\wedge}$ & 6 & $4.9 \%$ & 116 & $95.1 \%$ & \\
\hline - Injection & 14 & $28.0 \%$ & 36 & $72.0 \%$ & \\
\hline - Capsule & 1 & $5.6 \%$ & 17 & $94.4 \%$ & \\
\hline - Condom & 0 & $0 \%$ & 12 & $100.0 \%$ & \\
\hline \multicolumn{5}{|c|}{ Vaginal infection (20) } & \\
\hline - $\mathrm{OCP}^{\$}$ & 0 & $0 \%$ & 99 & $100.0 \%$ & \multirow{6}{*}{$\begin{array}{c}\mathrm{FE}=28.918^{\#} \\
\mathrm{P}=.000^{*} *\end{array}$} \\
\hline - IUD $^{\wedge}$ & 20 & $16.4 \%$ & 102 & $83.6 \%$ & \\
\hline - Injection & 0 & $0 \%$ & 50 & $100.0 \%$ & \\
\hline - Capsule & 0 & $0 \%$ & 18 & $100.0 \%$ & \\
\hline - Condom & 0 & $0 \%$ & 12 & $100.0 \%$ & \\
\hline \multicolumn{5}{|c|}{ Bleeding (18) } & \\
\hline - OCP $\$$ & 4 & $4.0 \%$ & 95 & $96.0 \%$ & \multirow{6}{*}{$\begin{array}{c}\mathrm{FE}=4.103^{\#} \\
\mathrm{P}=.331\end{array}$} \\
\hline - $\quad$ IUD $^{\wedge}$ & 12 & $9.8 \%$ & 110 & $90.2 \%$ & \\
\hline - Injection & 2 & $4.0 \%$ & 48 & $96.0 \%$ & \\
\hline - Capsule & 0 & $0 \%$ & 18 & $100.0 \%$ & \\
\hline - Condom & 0 & $0 \%$ & 12 & $100.0 \%$ & \\
\hline \multicolumn{5}{|c|}{ Weight gain (8) } & \\
\hline - $\mathrm{OCP}^{\$}$ & 5 & $5.1 \%$ & 94 & $32.1 \%$ & \multirow{5}{*}{$\begin{array}{c}\mathrm{FE}=4.204^{\#} \\
\mathrm{P}=.308\end{array}$} \\
\hline - IUD $^{\wedge}$ & 1 & $0.8 \%$ & 121 & $41.3 \%$ & \\
\hline - Injection & 2 & $4.0 \%$ & 48 & $16.4 \%$ & \\
\hline - Capsule & 0 & $0 \%$ & 18 & $6.1 \%$ & \\
\hline - Condom & 0 & $0 \%$ & 12 & $4.1 \%$ & \\
\hline \multicolumn{5}{|c|}{ GIT disturbance (9) } & \multirow{6}{*}{$\begin{array}{c}\mathrm{FE}=6.052^{\#} \\
\mathrm{P}=.142\end{array}$} \\
\hline - $\mathrm{OCP}^{\$}$ & 7 & $7.1 \%$ & 92 & $94.9 \%$ & \\
\hline - IUD $^{\wedge}$ & 2 & $1.6 \%$ & 120 & $99.2 \%$ & \\
\hline - Injection & 0 & $0 \%$ & 50 & $96.0 \%$ & \\
\hline - Capsule & 0 & $0 \%$ & 18 & $100.0 \%$ & \\
\hline - Condom & 0 & $0 \%$ & 12 & $100.0 \%$ & \\
\hline
\end{tabular}

"Fisher exact test; was used as $20 \%$ of the cells or more have expected count less than 5

** highly statistically significant at $\mathrm{P}<0.01$

${ }^{\wedge}$ IUD: Intrauterine Device

${ }^{\$}$ OCP: Oral Contraceptive Pills 


\section{العوائق التي تواجه تنظيم الأسرة بعد الولادة بين النساء المترددات على وحدات طب الأسرة في الحي السادس بمدينة 6 أكتوبر}

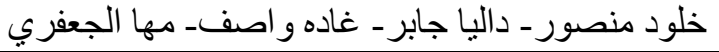

الخلفية:عالميا يعتبر لتنظيم الاسرة بعد الولادة دورهام في سلامة الأم والطفل حيث انه يركز على الوقاية من حدوث الحمل غير المقصودة، و منع حدوث حمل متقارب خلال الأشهر ال 12 الأولى بعد الولادة، ذلك يعود الي ان الحاجة غير الملباة لتنظيم الأسرة تكون عالية خلال فترة ما بعد الولادة مع وجود إمكانية منع النتائج السلبية لحدوث حمل بهذه الفتره ـهذا ادي الي اهمية معرفة الحواجز الريئسيه لتنظيم الاسره بعد الولاده و توفير طرق الحلول المناسبه و من هذه الحلول الاتجاه الي دمج معلومات تنظيم الأسرة وتقديم خدماته خلال رعاية ما بعد الولادة وزيارات الرعاية الصحية للاطفال وهذا على جميع مستويات النظام الصحي. الهدف: قياس معدل استخدام تنظيم الاسرة بعد الولادة بين النساء المترددات على وحدات طب الأسرة في الحي السادس في مدينة السادس من أكتوبر وتحديد تأثثر تنظيم الاسرة بعد الولادة على المباعدة بين الحمل وتحديد العقبات الرئيسية التي تواجه استمر ارية استخدام تتظيم الاسرة بعد الو لادة .المنهجية و طرق البحث: ان هذه الدر اسة در اسه مقطعية اجريت في الفتره من يوليو اتوبر 2017م واثتملت علي النساء المتزوجات في سن الإنجاب الاتى يحضرن وحدات طب الأسرة بالحي السادس في مدينة السادس اكتوبر وقد جمعت البيانات عن طريق استبيان بحوار شخصي من المشاركات .النتائج: اظهرت النتائج ان4و59 ٪ من المشاركات اللاتي تم سؤ الهن نتر اوح اعمار هن بين 25-35 سنة مع متوسط عمر 30 ـ 6.4 سنة ، ووجد ان معدل تنظيم الاسرة بعد الو لاده هو 8و 51 ٪ ، و ذكرت أكثر من نصف النساء المشاركات أن "نقص المعرفة حول تنظيم الاسره " بمثابة الحاجز الرئيسي لاستخدام الوسيله، تليها "الرغبة في انجاب المزيد من الأطفال" بنسبة 2و 42٪. الخلاصة: ينبغي توجيه أطباء الأسرة نحو دور هم الأساسي في تعزيز تنظيم الاسره بعد الولاده ، ليس فقط زيادة اتجاه النساء نحو منع الحمل بعد الولادة ، ولكن الحفاظ على

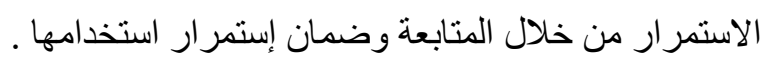

